\title{
PENERAPAN MODEL PEMBELAJARAN BERBALIK UNTUK MENINGKATKAN AKTIVITAS DAN HASIL BELAJAR SISWA KELAS XII IPS 2 SMAN PAKUSARI JEMBER (Studi Kasus Pada Mata Pelajaran Ekonomi Materi Jurnal Khusus Semester Genap Tahun Ajaran 2018/2019)
}

\author{
Siti Halimatus Sa'dia ${ }^{1}$, Titin Kartini ${ }^{1}$, Sri Kantun ${ }^{1}$ \\ ${ }^{1}$ Pendidikan Ekonomi, Fakultas Keguruan dan Ilmu Pendidikan, Universitas Jember \\ Jalan Kalimantan 37, Jember 68121 \\ E-mail: diasadia64@gmail.com
}

\begin{abstract}
Abstrak
Penelitian ini bertujuan untuk mendeskripsikan penerapan model pembelajaran berbalik dalam meningkatkan aktivitas dan hasil belajar siswa kelas XII IPS 2 SMAN Pakusari Jember pada mata pelajaran ekonomi materi jurnal khusus semester genap tahun ajaran 2018/2019, serta mengetahui peningkatan aktivitas dan hasil belajar siswa kelas XII IPS 2 SMAN Pakusari Jember. Penelitian ini merupakan penelitian tindakan kelas yang dilaksanakan dengan 2 siklus yang terdiri dari beberapa tahapan yakni tahap perencanaan, tindakan, observasi dan refleksi. Metode pengumpulan data yang digunakan dalam penelitian ini yakni metode observasi, tes, wawancara dan dokumen. Hasil penelitian ini menunjukkan bahwa penerapan model pembelajaran berbalik dapat meningkatkan aktivitas dan hasil belajar siswa kelas XII IPS 2 SMAN Pakusari Jember pada mata pelajaran ekonomi materi jurnal khusus semester genap tahun ajaran 2018/2019. Pada siklus I, aktivitas belajar siswa mencapai skor rata-rata 2,4 pada kategori sedang dan meningkat sebesar 0,9 menjadi 3,3 pada kategori tinggi pada siklus II. Sedangkan hasil belajar siswa dapat dilihat dari nilai rata-rata yang didapat dari tugas studi kasus dan ulangan harian pada mata pelajaran ekonomi materi jurnal khusus. Hasil penelitian menunjukkan bahwa pada siklus I, nilai rata-rata sis wa mencapai 79,9 dengan ketuntasan klasikal sebesar 79,4\%, kemudian mengalami peningkatan pada siklus II dengan nilai rata-rata 87,1 dan ketuntasan klasikal sebes ar $88,2 \%$.
\end{abstract}

Kata Kunci : $\quad$ Model Pembelajaran Berbalik, Aktivitas Belajar, Hasil Belajar, Materi Akuntansi

\section{PENDAHULUAN}

Proses interaksi aktif antara guru dan siswa untuk mencapai tujuan pembelajaran merupakan arti dari proses pembelajaran. Proses pembelajaran tidak akan berhasil apabila tidak didukung dengan komponen-komponen dalam pembelajaran. Komponen yang mempengaruhi proses pembelajaran meliputi guru, siswa, kurikulum, sarana, prasarana, dan model pembelajaran yang tepat. Pembelajaran dikatakan berhasil apabila sebagian besar siswa terlibat secara aktif dalam proses pembelajaran (Rusman, 2017:242).

Aktivitas belajar penting dalam proses pembelajaran. Hal tersebut dikarenakan dengan adanya aktivitas belajar siswa dalam proses pembelajaran akan membawa dampak bagi pembelajaran. Menurut Yamin (2007:82) aktivitas belajar ini terkait dengan siswa mampu membaca materi yang akan dipelajari, siswa berdiskusi dengan teman mengenai topik yang diberikan oleh guru, siswa bertanya kepada guru atau teman, siswa menyimak penjelasan dari guru, siswa membuat catatan tentang materi pembelajaran, siswa menanggapi pendapat teman atau guru, siswa mengerjakan tes secara individu, serta semangat siswa dalam mengikuti pembelajaran.

Berdasarkan hasil wawancara dilakukan peneliti dengan guru mata pelajaran ekonomi SMAN Pakusari Jember, diperoleh informasi bahwa ketika proses pembelajaran pada materi sebelumnya, aktivitas siswa hanya mendengarkan dan mencatat seperlunya saja apa yang dijelaskan oleh guru, tidak ada rasa keingintahuan siswa dalam pelajaran, dan siswa kurang bersemangat dalam mengikuti proses pembelajaran. Aktivitas belajar siswa yang rendah pada saat proses pembelajaran, berdampak terhadap hasil belajar siswa.

Hasil belajar merupakan perubahan perilaku yang diperoleh siswa setelah adanya aktivitas belajar dalam proses pembelajaran. Siswa yang berhasil dalam belajar adalah siswa yang mencapai 
tujuan pembelajaran atau siswa yang mencapai KKM yang telah ditentukan. Keberhasilan siswa dalam proses pembelajaran diketahui dari penguasaan materi pelajaran yang telah dipelajarinya. Berdasarkan dokumen dari guru mata pelajaran ekonomi kelas XII IPS SMAN Pakusari Jember, hasil belajar siswa terendah berada dikelas XII IPS 2, yang mana hasil belajar yang diperoleh kelas XII IPS 2 belum memenuhi kriteria ketuntasan minimal (KKM) yang telah ditentukan yakni $\geq 77$.

Materi jurnal khusus merupakan salah satu materi dalam pelajaran ekonomi kelas XII. Menurut informasi dari guru mata pelajaran ekonomi SMAN Pakusari Jember, jurnal khusus merupakan salah satu materi yang sulit yang membutuhkan ketelitian serta membutuhkan analisis dalam mengerjakannya. Sehingga, diperlukan tingkat pemahaman siswa yang lebih untuk mengingat mengenai konsepnya. Oleh karena itu, diperlukan suatu model pembelajaran yang dapat membantu dalam memudahkan pemahaman siswa terhadap materi jurnal khusus.

Berdasarkan permasalahan di atas, maka guru dan peneliti ingin meningkatkan aktivitas dan hasil belajar siswa dengan menerapkan model pembelajaran berbalik. Model pembelajaran berbalik merupakan salah satu model pembelajaran yang berpusat pada siswa yang melibatkan siswa aktif dalam proses pembelajaran serta dapat memudahkan siswa untuk memahami materi pelajaran. Huda (2016:216) mengatakan bahwa model pembelajaran berbalik dapat diterapkan kepada siswa melalui empat strategi yaitu berdiskusi kelompok, membuat pertanyaan, menjelaskan materi kepada teman lainnya dan mengerjakan latihan soal secara individu.

Berdasarkan penjelasan di atas, penelitian bertujuan untuk mendeskripsikan penerapan model pembelajaran berbalik dalam meningkatkan aktivitas dan hasil belajar siswa kelas XII IPS 2 SMAN Pakusari Jember pada mata pelajaran ekonomi materi jurnal khusus semester genap tahun ajaran 2018/2019, serta mengetahui peningkatan aktivitas dan hasil belajar siswa kelas XII IPS 2 SMAN Pakusari Jember.

\section{METODE}

Penelitian ini merupakan penelitian tindakan kelas yang dilaksanakan dengan 2 siklus yang terdiri dari beberapa tahapan yakni tahap perencanaan, tindakan, observasi dan refleksi. Subjek penelitian ini adalah seluruh siswa kelas XII IPS 2 SMAN Pakusari Jember tahun ajaran 2018/2019 berjumlah 34 siswa. Metode pengumpulan data yang digunakan dalam penelitian ini yakni metode observasi, tes, wawancara dan dokumen. Penelitian ini menggunakan analisis data secara deskriptif dengan pendekatan kualitatif yakni memaparkan data yang diperoleh oleh peneliti dari hasil pelaksanaan tindakan. Instrumen penelitian menggunakan lembar observasi aktivitas siswa, lembar observasi kegiatan guru, tes hasil belajar dan catatan lapangan.

\section{HASIL DAN PEMBAHASAN \\ Hasil Penelitian}

Hasil penelitian ini terbagi dalam 2 siklus. Hasil penelitian siklus I diperoleh dari hasil observasi selama pelaksanaan tindakan pada pembelajaran pertemuan pertama dan pertemuan kedua. Proses pembelajaran pada siklus I berjalan dengan baik walaupun terdapat beberapa kendala yaitu aktivitas siswa pada pertemuan pertama ketika berdiskusi tidak memperhatikan pendapat teman dan tidak menanggapi, ada beberapa siswa yang hanya diam saja tidak bertanya kepada teman atau guru, dan siswa tidak mencatat materi jurnal khusus di buku catatan. Adapun hasil observasi aktivitas belajar siswa, sebagai berikut:

Tabel 1 Aktivitas Belajar Siswa pada Siklus I

\begin{tabular}{llcccc}
\hline No. & \multicolumn{1}{c}{ Indikator } & $\begin{array}{c}\text { Skor } \\
\text { Pertemuan } \\
\text { I }\end{array}$ & $\begin{array}{c}\text { Skor } \\
\text { Pertemuan } \\
\text { II }\end{array}$ & $\begin{array}{c}\text { Skor } \\
\text { rata- } \\
\text { rata }\end{array}$ & Kategori \\
\hline 1 & $\begin{array}{l}\text { Siswa mampu membaca materi } \\
\text { jurnal khusus }\end{array}$ & 2,3 & 2,4 & 2,4 & Sedang \\
\hline 2 & Siswa berdiskusi dengan teman & 2,5 & 2,8 & 2,7 & Sedang \\
\hline 3 & $\begin{array}{l}\text { Siswa bertanya kepada guru atau } \\
\text { teman }\end{array}$ & 2,0 & 2,3 & 2,2 & Sedang \\
\hline
\end{tabular}




\begin{tabular}{llllll}
\hline 4 & $\begin{array}{l}\text { Siswa menyimak penjelasan dari } \\
\text { guru }\end{array}$ & 2,6 & 2,7 & 2,7 & Sedang \\
\hline 5 & $\begin{array}{l}\text { Siswa membuat catatan tentang } \\
\text { materi jurnal khusus }\end{array}$ & 2,2 & 2,4 & 2,3 & Sedang \\
\hline 6 & $\begin{array}{l}\text { Siswa menanggapi pendapat } \\
\text { teman atau guru }\end{array}$ & 2,0 & 2,1 & 2,1 & Sedang \\
\hline 7 & $\begin{array}{l}\text { Siswa mengerjakan tes dengan } \\
\text { kemampuan sendiri }\end{array}$ & 2,4 & 2,6 & 2,5 & Sedang \\
\hline 8 & $\begin{array}{l}\text { Siswa bersemangat dalam } \\
\text { mengikuti pembelajaran }\end{array}$ & 2,4 & 2,7 & 2,6 & Sedang \\
\hline & Rata-rata aktivitas belajar sis wa \\
siklus I
\end{tabular}

Sumber : Data primer yang diolah

Tabel di atas menunjukkan bahwa rata-rata indikator aktivitas belajar siswa dalam kategori sedang. Pada siklus I indikator aktivitas belajar siswa skor rata-rata pertemuan I mencapai 2,3 dan skor rata-rata pada pertemuan II mencapai 2,5 sehingga dapat disimpulkan bahwa skor rata-rata aktivitas belajar siswa pada siklus I sebesar 2,4 pada kategori sedang. Dapat dilihat dari tabel di atas bahwasanya skor rata-rata aktivitas belajar pada siklus I tertinggi yakni pada indikator siswa berdiskusi dengan teman dan siswa menyimak penjelasan dari guru. Sedangkan skor terendah pada indikator siswa menanggapi pendapat teman atau guru dan siswa bertanya kepada guru atau teman.

Aktivitas belajar juga berdampak terhadap hasil belajar siswa, yang ditunjukkan dengan nilai rata-rata yang diperoleh dari nilai tugas studi kasus dan nilai ulangan harian yang masing-masing bobotnya yakni 4 dan 6 pada materi jurnal khusus. Hasil belajar siswa yang diperolah pada siklus I dapat dilihat pada tabel berikut ini :

Tabel 2 Hasil Belajar Siswa pada Siklus I

\begin{tabular}{cccccc}
\hline Kelas & $\begin{array}{c}\text { Jumlah } \\
\text { Siswa }\end{array}$ & $\begin{array}{c}\text { Nilai rata- } \\
\text { rata }\end{array}$ & $\begin{array}{c}\text { Jumlah } \\
\text { Siswa yang } \\
\text { Tuntas }\end{array}$ & $\begin{array}{c}\text { Jumlah } \\
\text { Siswa } \\
\text { Tidak } \\
\text { Tuntas }\end{array}$ & $\begin{array}{c}\text { Ketuntasan } \\
\text { Klasikal }\end{array}$ \\
\hline XII IPS 2 & 34 & 79,9 & 27 & 7 & $79,4 \%$ \\
\hline
\end{tabular}

Sumber : Data primer yang diolah

Berdasarkan tabel di atas, dapat dilihat bahwa nilai rata-rata siswa 79,9 dan ketuntasan klasikal mencapai 79,4\%. Ketuntasan klasikal pada siklus I sudah mencapai kriteria ketuntasan minimal (KKM) yaitu $75 \%$.

Pada siklus I, aktivitas belajar siswa berada pada kategori sedang dan hasil belajar cukup baik. Oleh karena itu, perlu dilakukan siklus II sebagai proses pemantapan dari pelaksanaan siklus I serta untuk memperbaiki kekurangan-kekurangan yang terjadi pada pelaksanaan siklus I.

Hasil penelitian pada siklus II diperoleh dari hasil observasi selama pelaksanaan tindakan pada pembelajaran pertemuan pertama dan pertemuan kedua. Guru melakukan kegiatan pembelajaran sesuai dengan rencana perbaikan pembelajaran untuk pemantapan dari siklus I. Aktivitas belajar siswa pada siklus II mengalami peningkatan dan termasuk dalam kategori tinggi. Hal tersebut dapat dilihat dari sebagian besar siswa menjadi lebih aktif dalam pelajaran ekonomi materi jurnal khusus. Adapun hasil observasi aktivitas belajar siswa sebagai berikut :

Tabel 3 Aktivitas Belajar Siswa pada Siklus II

\begin{tabular}{lllccc}
\hline No. & \multicolumn{1}{c}{ Indikator } & $\begin{array}{c}\text { Skor } \\
\text { Pertemuan } \\
\text { I }\end{array}$ & $\begin{array}{c}\text { Skor } \\
\text { Pertemuan } \\
\text { II }\end{array}$ & $\begin{array}{c}\text { Skor } \\
\text { rata- } \\
\text { rata }\end{array}$ & Kategori \\
\hline 1 & $\begin{array}{l}\text { Siswa membaca } \\
\text { khusus }\end{array}$ & 3,2 & 3,4 & 3,3 & Tinggi \\
\hline 2 & Siswa berdiskusi dengan teman & 3,1 & 3,5 & 3,3 & Tinggi \\
\hline 3 & $\begin{array}{l}\text { Siswa bertanya kepada guru atau } \\
\text { teman }\end{array}$ & 2,9 & 3,2 & 3,1 & Tinggi \\
\hline
\end{tabular}




\begin{tabular}{llllll}
\hline 4 & $\begin{array}{l}\text { Siswa menyimak penjelasan dari } \\
\text { guru }\end{array}$ & 3,3 & 3,4 & 3,4 & Tinggi \\
\hline 5 & $\begin{array}{l}\text { Siswa membuat catatan tentang } \\
\text { materi jurnal khusus }\end{array}$ & 3,0 & 3,3 & 3,2 & Tinggi \\
\hline 6 & $\begin{array}{l}\text { Siswa menanggapi pendapat } \\
\text { teman atau guru }\end{array}$ & 2,8 & 3,3 & 3,1 & Tinggi \\
\hline 7 & $\begin{array}{l}\text { Siswa mengerjakan tes dengan } \\
\text { kemampuan sendiri }\end{array}$ & 3,2 & 3,5 & 3,4 & Tinggi \\
\hline 8 & $\begin{array}{l}\text { Siswa bersemangat dalam } \\
\text { mengikuti pembelajaran }\end{array}$ & 3,4 & 3,7 & 3,6 & Tinggi \\
\hline $\begin{array}{l}\text { Rata-rata aktivitas belajar sis wa } \\
\text { siklus II }\end{array}$ & $\mathbf{3 , 1}$ & $\mathbf{3 , 4}$ & $\mathbf{3 , 3}$ & Tinggi \\
\hline
\end{tabular}

Sumber : Data primer yang diolah

Tabel 3 menunjukkan bahwa rata-rata indikator aktivitas belajar siswa dalam kategori tinggi dari keseluruhan indikator. Skor tertinggi pada indikator siswa bersemangat dalam mengikuti pembelajaran. Skor rata-rata aktivitas belajar siswa pada siklus II mencapai 3,3 pada kategori tinggi. Pada siklus II dapat disimpulkan bahwa pembelajaran dengan menerapkan model pembelajaran berbalik dapat meningkatkan aktivitas belajar siswa kelas XII IPS 2.

Aktivitas belajar siswa yang meningkat juga berdampak terhadap hasil belajar siswa yang ditunjukkan dengan nilai akhir pada materi jurnal khusus yang diperoleh dari tugas studi kasus dan ulangan harian yang masing-masing bobotnya 4 dan 6 . Hasil belajar siswa yang diperoleh pada siklus II dapat dilihat pada tabel berikut ini :

Tabel 4 Hasil Belajar Siswa pada Siklus II

\begin{tabular}{cccccc}
\hline Kelas & $\begin{array}{c}\text { Jumlah } \\
\text { Siswa }\end{array}$ & $\begin{array}{c}\text { Nilai rata- } \\
\text { rata }\end{array}$ & $\begin{array}{c}\text { Jumlah } \\
\text { Siswa yang } \\
\text { Tuntas }\end{array}$ & $\begin{array}{c}\text { Jumlah } \\
\text { Siswa } \\
\text { Tidak } \\
\text { Tuntas }\end{array}$ & $\begin{array}{c}\text { Ketuntasan } \\
\text { Klasikal }\end{array}$ \\
\hline XII IPS 2 & 34 & 87,1 & 30 & 4 & $88,2 \%$ \\
\hline
\end{tabular}

Sumber : Data primer yang diolah

Berdasarkan tabel di atas, dapat dilihat bahwa nilai rata-rata mencapai 87,1 dan ketuntasan klasikal mencapai $88,2 \%$. Hal tersebut menunjukkan bahwa hasil belajar siswa sudah memenuhi target pembelajaran pada siklus II. Dengan demikian, terjadi peningkatan dari siklus I ke siklus II. Peningkatan aktivitas belajar siswa pada siklus I dan siklus II dapat dilihat pada tabel berikut ini :

Tabel 5 Rekapitulasi Aktivitas Belajar Siswa Kelas XII IPS 2 SMAN Pakusari Jember

\begin{tabular}{cccc}
\hline No. & Siklus & $\begin{array}{c}\text { Skor Rata-rata Aktivitas Belajar } \\
\text { Sis wa }\end{array}$ & Krite ria \\
\hline 1 & Siklus I & 2,4 & Sedang \\
\hline 2 & Siklus II & 3,3 & Tinggi \\
\hline & Peningkatan & $\mathbf{0 , 9}$ & \\
\hline
\end{tabular}

Sumber : Data primer yang diolah

Tabel 5 menunjukkan bahwa terjadi peningkatan aktivitas belajar siswa dari siklus I ke siklus II. Aktivitas belajar siswa pada siklus I sebesar 2,4 pada kategori sedang dan meningkat pada siklus II sebesar 0,9 sehingga menjadi 3,3 pada kategori tinggi.

Peningkatan aktivitas belajar juga berdampak terhadap hasil belajar siswa. Hal ini dapat dilihat dari hasil belajar siswa yang diperoleh dari siklus I ke siklus II pada tabel berikut ini :

Tabel 6 Rekapitulasi Hasil Belajar Siswa Kelas XII IPS 2 SMAN Pakusari Jember

\begin{tabular}{lcccc}
\hline No. & Siklus & Jumlah Siswa & Nilai rata-rata & $\begin{array}{c}\text { Ketuntasan } \\
\text { Klasikal }\end{array}$ \\
\hline 1 & I & 34 & 79,9 & $79,4 \%$ \\
\hline 2 & II & 34 & 87,1 & $88,2 \%$ \\
\hline \multicolumn{7}{c}{ Peningkatan } & $\mathbf{7 , 2}$ & $\mathbf{8 , 8 \%}$ \\
\hline
\end{tabular}

Sumber : Data primer yang diolah 
Pada tabel di atas dapat dilihat bahwa terjadi peningkatan pada hasil belajar siswa. Peningkatan sebesar 7,2 nilai rata-rata siswa dari 79,9 menjadi 87,1. Sedangkan peningkatan ketuntasan klasikal mencapai $8,8 \%$ dari $79,4 \%$ menjadi $88,2 \%$. Hal tersebut dapat dilihat pada gambar berikut ini :

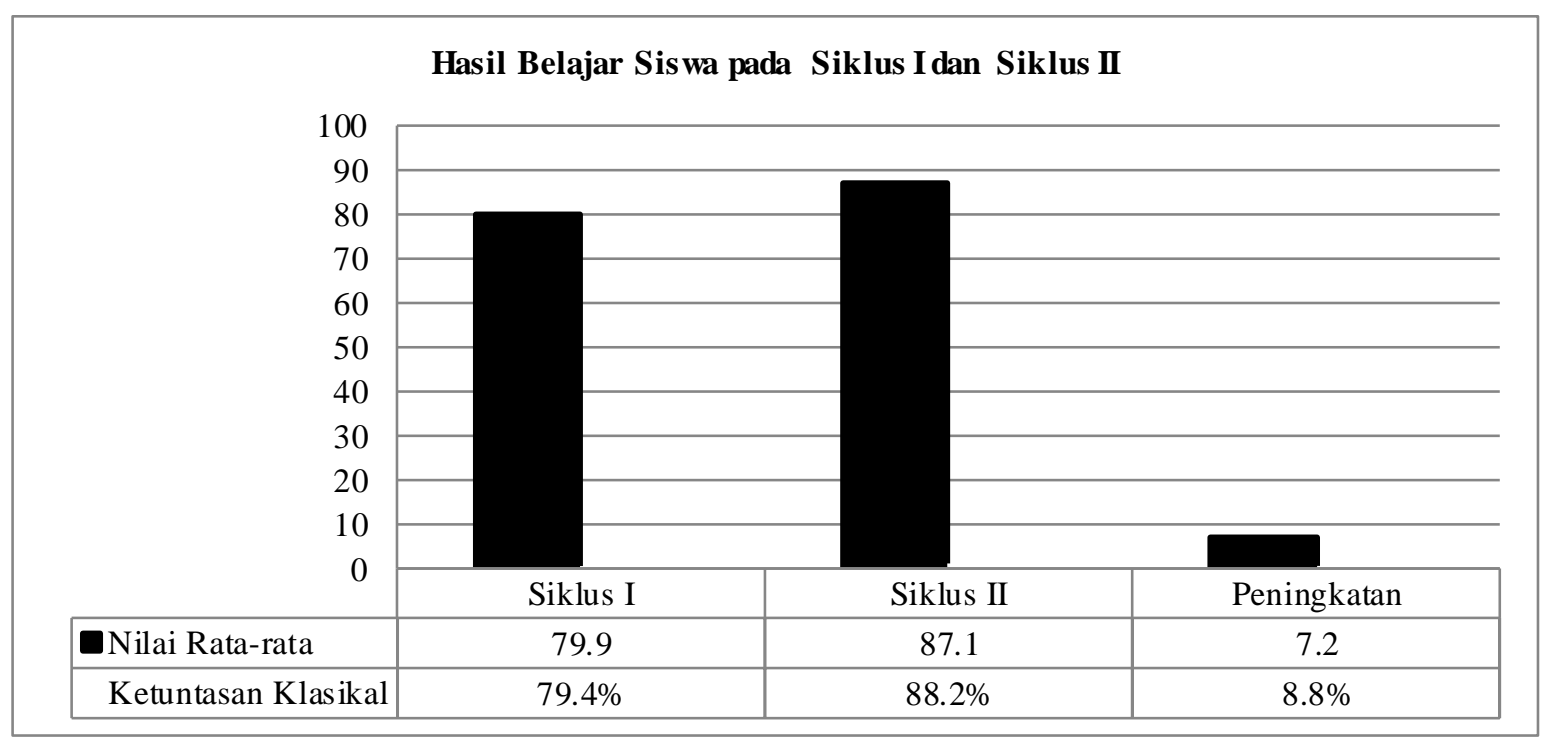

Gambar 1 Peningkatan hasil belajar siswa dari siklus I ke siklus II

Pelaksanaan siklus II sudah mencapai target yang telah ditentukan, yakni aktivitas belajar pada kategori tinggi dan hasil belajar sudah sangat baik. Maka dari itu, peneliti memutuskan untuk menghentikan penelitian pada siklus II karena tujuan penelitian sudah tercapai.

\section{Pembahas an}

Penelitian ini telah dibuktikan bahwa penerapan model pembelajaran berbalik dapat meningkatkan aktivitas dan hasil belajar siswa kelas XII IPS 2 SMAN Pakusari Jember pada mata pelajaran ekonomi materi jurnal khusus. Dengan demikian, hipotesis tindakan penelitian yang diajukan terbukti.

Indikator aktivitas belajar siswa seperti, siswa mampu membaca materi jurnal khusus, siswa berdiskusi dengan teman, siswa bertanya kepada guru atau teman, siswa menyimak penjelas an dari guru, siswa membuat catatan mengenai jurnal khusus, siswa menanggapi pendapat teman atu guru, siswa mengerjakan tes dengan kemampuannya sendiri serta siswa semangat dalam mengikuti proses pembelajaran menunjukkan peningkatan kategori dari siklus I ke siklus II. Pada siklus I, aktivitas belajar siswa masih berada dikategori sedang dengan skor rata-rata 2,4. Hal tersebut disebabkan karena semua indikator aktivitas belajar siswa pada siklus I berada pada kategori sedang. Sehingga dilakukan perbaikan pada siklus II dan terjadi peningkatan sebesar 0,9 dengan rata-rata skor 3,3 pada siklus II. Sesuai dengan pendapat Shoimin (2014:153) bahwa model pembelajaran berbalik dalam proses pembelajaran menjadikan siswa belajar secara aktif, dimana siswa mempelajari materi secara bermakna dengan belajar dan berpikir. Trianto (2007:98) juga mengungkapkan bahwasanya model pembelajaran berbalik dapat membantu siswa untuk lebih aktif dalam proses pembelajaran, sehingga aktivitas belajar siswa meningkat.

Aktivitas belajar siswa yang meningkat berdampak terhadap hasil belajar siswa. Peningkatan hasil belajar dapat dilihat dari siklus I ke siklus II. Pada siklus I, nilai rata-rata siswa sebesar 79,9 dan meningkat sebesar 7,2 sehingga menjadi 87,1 pada siklus II. Sedangkan peningkatan ketuntasan klasikal dari siklus I ke siklus II sebesar 79,4\% meningkat 8,8\% menjadi 88,2\%. Seperti yang dikemukakan oleh Shoimin (2014: 156) bahwa model pembelajaran berbalik memiliki beberapa kelebihan, diantaranya memupuk kerjasama antar siswa, mengembangkan kreativitas siswa, melatih siswa untuk menjelaskan materi kepada teman, melatih kemampuan siswa dalam belajar mandiri, melatih siswa untuk menganalisis masalah dan mengambil kesimpulan, serta siswa lebih memperhatikan pelajaran karena menghayati sendiri dan siswa belajar secara bermakna dan berpikir. Rachmayani (2014:22) juga mengungkapkan bahwa model pembelajaran berbalik dapat menjadikan 
siswa lebih memahami materi yang diajarkan. Pendapat ini juga diperkuat oleh pernyataan dari guru mata peajaran ekonomi yang menyatakan bahwa :

“....model pembelajaran berbalik merupakan model yang pertama kali saya terapkan dalam proses pembelajaran khususnya pada siswa kelas XII IPS 2 SMAN Pakusari Jember. Saya lihat dengan menerapakan model pembelajaran berbalik siswa lebih aktif dalam proses pembelajaran. Selain itu, aktivitas siswa dalam proses pembelajaran juga sudah baik, siswa mau membaca materi dan melakukan diskusi kelompok dengan teman-temannya, siswa menyimak penjelasan yang guru sampaikan, siswa juga lebih aktif bertanya dan berpendapat, siswa juga mempunyai keberanian dalam menjelaskan materi terhadap teman-temannya serta siswa sangat bersemangat dalam mengikuti proses pembelajaran." (Ibu Anna, 35 tahun)

Siswa juga mengakui bahwa dengan menerapkan model pembelajaran berbalik dapat meningkatkan aktivitas dan hasil belajar mereka. Hal itu diketahui dari pernyataan salah satu siswa kelas XII IPS 2 SMAN Pakusari Jember yang mengatakan bahwa :

“....saya senang dengan adanya penerapan model pembelajaran berbalik dalam proses pembelajaran. Selain siswa lebih aktif dalam proses pembelajaran, saya juga lebih paham mengenai materi yang dipelajari. Model pembelajaran berbalik menurut saya berdampak positif terhadap kami, yang mana siswa lebih bersemangat dalam mengikuti proses pembelajaran, selain itu siswa juga antusias untuk bertanya dan mengemukakan pendapatnya. Saya pun juga merasakan kalau model pembelajaran berbalik ini membuat saya lebih aktif dan bersemangat dalam mengikuti proses pembelajaran daripada model yang sebelumnya guru terapkan." (Siswi NA, 17 th)

Berdasarkan hasil penelitian dan wawancara yang dilakukan peneliti dengan guru mata pelajaran ekonomi, siswa serta dukungan teori dapat disimpulkan bahwa dengan penerapan model pembelajaran berbalik dapat meningkatkan aktivitas dan hasil belajar siswa dalam proses pembelajaran. Hal tersebut dapat dilihat dari ketuntasan siswa dalam kegiatan belajar dan pemahaman siswa mengenai materi jurnal khusus yang dipelajari, sehingga model tersebut dapat diterapkan dalam proses pembelajaran.

\section{PENUTUP}

Berdasarkan hasil penelitian dan pembahasan, dapat disimpulkan bahwa penerapan model pembelajaran berbalik dapat meningkatkan aktivitas dan hasil belajar siswa kelas XII IPS 2 SMAN Pakusari Jember pada mata pelajaran ekonomi materi jurnal khusus semester genap tahun ajaran 2018/2019. Peningkatan aktivitas belajar siswa dilihat dari skor rata-rata aktivitas belajar pada siklus I sebesar 2,4 pada kategori sedang dan siklus II menjadi 3,3 pada kategori tinggi. Hasil belajar siswa pada siklus I mencapai nilai rata-rata 79,9 dengan ketuntasan klasikal sebesar 79,4\%, kemudian mengalami peningkatan pada siklus II dengan nilai rata-rata 87,1 dan ketuntasan klasikal sebesar $88,2 \%$.

Berdasarkan hasil penelitian ini, maka peneliti dapat memberikan saran yaitu sebaiknya guru menerapkan model pembelajaran yang tepat agar dapat meningkatkan aktivitas dan hasil belajar siswa, salah satunya guru dapat menerapkan model pembelajaran berbalik yang sudah dilakukan pada penelitian ini. 


\section{DAFTAR PUSTAKA}

Huda, M. 2016. Model-Model Pengajaran dan Pembelajaran. Yogyakarta: Pustaka Belajar

Rachmayani, D. 2014. Penerapan Pembelajaran Reciprocal Teaching Untuk Meningkatkan Kemampuan Komunikasi Matematis Dan Kemandirian Belajar Matematika Siswa. Unsika. ISSN: 2338-2996. Vol. 2, No. 1, PP 13-23.

Rusman. 2017. Belajar dan Pembelajaran Berorientasi Standar Proses Pendidikan. Jakarta: Kencana

Shoimin, A. 2014. 68 Model Pembelajaran Inovatif dalam Kurikulum 2013. Yogyakarta: Ar-Ruzz Media

Trianto. 2007. Model-model Pembelajaran Inovatif Berorientasi Konstruktivistik. Jakarta: Prestasi Pustaka

Yamin, M. 2007. Kiat Membelajarkan Siswa. Jakarta: Gaung Persada 